\title{
Research on Iris Pseudacorus and Sagittaria Sagittifolia's Accumulation Ability on Pb Tailings Exudated Liquids
}

\author{
Yao $\mathrm{Na}$ \\ College of Life Sciences, Engineering Research Center of the Chinese Ministry of Educationfor \\ Bioreactor and Pharmaceutical Development, Jilin Agricultural University,130118
}

Key Words: iris pseudacorus; sagittaria sagittifolia; $\mathrm{Pb}$ tailings

\begin{abstract}
The purpose of this experiment is to study the heavy metal pollution degree in two kinds of aquatic plants, iris pseudacorus and sagittaria sagittifolia, and accumulation effect on heavy metal pollutants, and compare the iris pseudacorus and sagittaria sagittifolia's tolerance on $\mathrm{Pb}$ tailings exudated liquids with different contents and these two kinds of plants' ability of remediating pollution water body environment with $\mathrm{Pb}$ heavy metals tailings in hoping of seeking the new breakthrough for the phytoremediation technology in this paper.

It is more difficult to degrade the heavy metal elements, and their toxicity is also very big. In addition, the heavy metal elements can also be accumulated and absorbed by the plants. Thus, the heavy metal elements enter the food chain and pose a serious threat to the healths of people, animals, all kinds of wild animals and other lives. Metallurgy, metal treatment, textile, paint, salt production, medicine, chemical industry, mining are the main source of heavy metal pollutants. Especially in mineral resource rich regions, once tailings, slags, toxic gases and industrial waste water, these industrial wastes with a lot of heavy metal pollutants, brought by mining operations are discharged into the surrounding environments, it will bring great harm to the healths of residents and other creatures in this region. In recent years, Dexing City, Jiangxi Province has been focused on economic development, and neglected environment protection. Because of special location of Dexing City, there are many lead mines in its territory. In the process of exploiting the mines, at the same time, Dexing people have neglected the treatment of discarded tailings so as to make tailings exudated liquids flow into the rivers to lead to that the residents living water and agricultural water contain a large amount of $\mathrm{Pb}$ and bring great harm to people's production and life. Therefore, we must find the plants with good tolerance and strong vitality and use these plants' self-remediation abilities and abilities of remediating the surrounding environment so as to relieve increasingly the serious ecological environment in mining regions, Dexing City, Jiangxi Province.
\end{abstract}

\section{Materials and Methods}

\subsection{Experimental Materials}

The experimental plants, iris pseudacorus seeds and sagittaria sagittifolia bulbs are purchased from Hongcheng big market in Nanchang City, Jiangxi Province.

As far as the experimental solution is concerned, the exudated liquids are obtained after the precipitation of discarded tailings in lead mines regions, Dexing City, Jiangxi Province, namely $\mathrm{Pb}$ tailings exudated liquids (PbL), and they are used for the experiment.

\subsection{Methods}

\subsubsection{Seedling Cultivation and Treatment of Pb Tailings Exudated Liquids}

After we obtain iris pseudacorus seeds and sagittaria sagittifolia bulbs, first we have been planted them for a period of time to ensure that their growing environments and the time are consistent. We don't treat the two kinds of plants until the seedlings lengths of the two kinds of plants both reach $10 \mathrm{~cm}$ or so. We mainly adopt Han Yulin and other people's methods to treat the seedlings. After we select the uniform seedlings to cultivate them for a week so as to restore their growths in $1 / 4$ Hoagland nutrient(HN), we plant four seelings respectively in plastic basin with the size of $10 \mathrm{~cm} \times 15 \mathrm{~cm}$ to conduct $\mathrm{Pb}$ tailings exudated liquids treatment.

We conduct five treatments, namely $75 \% 1 / 4$ Hoagland nutrient $+25 \% \mathrm{~Pb}$ tailings exudated liquids, $50 \% 1 / 4$ Hoagland nutrient $+50 \% \mathrm{~Pb}$ tailings exudated liquids, $25 \% 1 / 4$ Hoagland nutrient 
$+75 \% \mathrm{~Pb}$ tailings exudated liquids, $25 \% 1 / 4$ Hoagland nutrient $+100 \% \mathrm{~Pb}$ tailings exudated liquids, $25 \% 1 / 4$ Hoagland nutrient $+25 \% \mathrm{~Pb}$ tailings exudated liquids respectively. We repeat each treatment for three times. We place the two kinds of plants in the laboratory facing the sun to let them grow with $25{ }^{\circ} \mathrm{C}$ average temperature and 35000Lux average light. In the treatment period according to the specific conditions we supply the two kinds of plants with a certain amount of water every morning and evening. After 60 days of treatment, we take samples to measure the photosynthetic pigment content and do the electron microscopy observation of plant leaves and root tissue structures.

\subsubsection{Measuring Methods}

We use HQ30d American hash portable tester to measure and use the nutrient dissolved oxygen (DO), electrical conductivity(EC), and PH.

We adopt Jiang Zhaofa and other people's methods to calculate plants tolerance index. We adopt Luo Yaping and other people's methods to calculate translocation factor.

Tolerance index $(\mathrm{TI} \%)=$ plants root length of $\mathrm{Pb}$ tailings exudated liquids with different contents in treatment group/plants root length in control group $\times 100 \%$

Translocation Factor(TF)=the heavy metal content of plants above-ground part/the heavy metal content of plants under-ground part $\times 100 \%$

\subsection{Data Calculation and Statistical Analysis}

About calculation and analysis of experiment data, we adopt Excel 2003, WPS Office system and SPSS linear regression analysis software to conduct, and use the STST analysis software to do difference significance analysis on experimental data. When $\mathrm{P}<0.05$, there is significant difference.

\section{Results and Analysis}

\subsection{Effects of Pb Tailings Exudated Liquids Stress on the Growth of Iris Pseudacorus and}

\section{Sagittaria Sagittifolia}

According to data from Table 5-1, under the treatment of $\mathrm{Pb}$ tailings exudated liquids with different volume fractions, Sagittaria Sagittifolia's change trend of each item growth index is similar with iris pseudacorus. Four kinds of growth indexes all show a decreasing trend. Under the treatment of pure $\mathrm{Pb}$ liquids, seeding height, root length, above-ground part and under-ground part in dry weight, and tolerance index of Sagittaria Sagittifolia are 64\%, 55\%, 26\%, 15\% and 55\% of treatment in control group respectively. Seen from tolerance index, this growth index, Sagittaria Sagittifolia's number value is smaller than iris pseudacorus. Thus, it reflects that under the $\mathrm{Pb}$ tailings exudated liquids stress with the same volume concentration, iris pseudacorus's tolerance is stronger than Sagittaria Sagittifolia.

Table 5-1 Effects of PbL stress on the growth indexes of I. pseudacorus and S. sagittifolia $(X \pm S D)^{1}$

\begin{tabular}{ccccccc}
\hline Species & Treatment & $\begin{array}{c}\text { Seeding } \\
\text { height/cm }\end{array}$ & $\begin{array}{c}\text { Root } \\
\text { length/cm }\end{array}$ & $\begin{array}{c}\text { Dry weight/g } \\
\text { Above-ground } \\
\text { part }\end{array}$ & $\begin{array}{c}\text { Under-ground } \\
\text { part }\end{array}$ & $\begin{array}{c}\text { Tolerance } \\
\text { index/\% }\end{array}$ \\
\hline & $0 \%$ & $36.89 \pm 2.50 \mathrm{a}$ & $29.61 \pm 1.61 \mathrm{a}$ & $0.21 \pm 0.01 \mathrm{a}$ & $0.15 \pm 0.02 \mathrm{a}$ & 100.00 \\
iris & $25 \%$ & $33.82 \pm 4.93 \mathrm{ab}$ & $27.61 \pm 1.61 \mathrm{ab}$ & $0.15 \pm 0.01 \mathrm{~b}$ & $0.10 \pm 0.04 \mathrm{~b}$ & 93.00 \\
pseudacoru & $75 \%$ & $34.76 \pm 1.77 \mathrm{ab}$ & $28.12 \pm 3.65 \mathrm{ab}$ & $0.18 \pm 0.02 \mathrm{a}$ & $0.14 \pm 0.05 \mathrm{ab}$ & 95.00 \\
$\mathrm{~s}^{1}$ & $100 \%$ & $31.84 \pm 3.47 \mathrm{ab}$ & $24.64 \pm 2.98 \mathrm{bc}$ & $0.12 \pm 0.02 \mathrm{c}$ & $0.10 \pm 0.02 \mathrm{~b}$ & 83.00 \\
& $0 \%$ & $16.06 \pm 4.65 \mathrm{a}$ & $24.06 \pm 4.67 \mathrm{a}$ & $0.19 \pm 0.06 \mathrm{a}$ & $0.13 \pm 0.04 \mathrm{a}$ & 100.00 \\
Sagittaria & $25 \%$ & $13.44 \pm 4.82 \mathrm{ab}$ & $21.56 \pm 5.73 \mathrm{ab}$ & $0.10 \pm 0.01 \mathrm{~b}$ & $0.07 \pm 0.01 \mathrm{~b}$ & 90.00 \\
Sagittifolia & $75 \%$ & $12.44 \pm 3.20 \mathrm{~b}$ & $17.11 \pm 4.91 \mathrm{bc}$ & $0.09 \pm 0.02 \mathrm{~b}$ & $0.08 \pm 0.03 \mathrm{~b}$ & 71.00 \\
& $100 \%$ & $13.50 \pm 3.14 \mathrm{ab}$ & $14.83 \pm 4.02 \mathrm{bc}$ & $0.06 \pm 0.01 \mathrm{~b}$ & $0.05 \pm 0.01 \mathrm{bc}$ & 62.00 \\
& $10.33 \pm 2.91 \mathrm{~b}$ & $13.17 \pm 5.53 \mathrm{c}$ & $0.05 \pm 0.02 \mathrm{~b}$ & $0.02 \pm 0.01 \mathrm{c}$ & 55.00 \\
\hline
\end{tabular}

Different small letters in the same column indicate the significant difference by Duncan's new multiple range test $(P<0.05)$.

\footnotetext{
${ }^{1}$ This data once were published in Journal of Jinan University (Natural Science and Medicine Edition), P252, the 3rd Issue, 2015.
} 


\subsection{Effects of $\mathrm{Pb}$ Tailings Exudated Liquids Stress on $\mathrm{Pb}$ accumulation and translocation}

\section{factors of Iris Pseudacorus and Sagittaria Sagittifolia}

Seen from Table 2, we know that in $\mathrm{Pb}$ tailings exudated liquids with different contents $\mathrm{Pb}$ accumulated amounts of above-ground part and under-ground part of the two kinds of aquatic plants, iris pseudacorus and sagittaria sagittifolia, are both higher than the control group and it has significant difference compared with the control group $(\mathrm{P}<0.05)$. In $75 \%$ of $\mathrm{PbL}$ treatment, $\mathrm{Pb}$ contents of above-ground part and under-ground part of iris pseudacorus are $90.42 \mu \mathrm{g} / \mathrm{g}$ and $173.29 \mu \mathrm{g} / \mathrm{g}$ respectively, and they are 14 times and 16 times of the control group, and it has significant difference $(\mathrm{P}<0.05)$. The above-ground part and under-ground part of iris pseudacorus take $100 \% \mathrm{PbL}$ treatment as the highest one, and they are $148.89 \mu \mathrm{g} / \mathrm{g}$ and $318.33 \mu \mathrm{g} / \mathrm{g}$ respectively, and they are higher $228 \%$ and $108 \%$ of the treatment in control group respectively. Pb content range of above-ground part of iris pseudacorus is from $50 \% \mathrm{PbL}$ to $75 \% \mathrm{PbL}$. Compared with the treatment range from $0 \% \mathrm{PbL}$ to $25 \% \mathrm{PbL}$, it has significant difference. $\mathrm{Pb}$ contents of under-ground part with different treatments all have significant differences $(\mathrm{P}<0.05)$.

In the treatment range from $0 \% \mathrm{PbL}$ to $100 \% \mathrm{PbL}$, under the treatment range from $25 \% \mathrm{PbL}$ to $75 \% \mathrm{PbL}$, compared with the control treatment $\mathrm{Pb}$ content of above-ground part of sagittaria sagittifolia has significant difference $(\mathrm{P}<0.05)$. In $100 \% \mathrm{PbL}$ treatment group $\mathrm{Pb}$ accumulated amount is the highest, namely $125 \mu \mathrm{g} / \mathrm{g}$ and it is 32 times of the control group. Pb contents of under-ground part of sagittaria sagittifolia with different treatments all have the differences, and they are $16.67 \mu \mathrm{g} / \mathrm{g}, 53.33 \mu \mathrm{g} / \mathrm{g}, 80.83 \mu \mathrm{g} / \mathrm{g}, 170.83 \mu \mathrm{g} / \mathrm{g}$ and $238.33 \mu \mathrm{g} / \mathrm{g}$ respectively. The highest $\mathrm{Pb}$ content is 14 times of the control group. The highest $\mathrm{Pb}$ accumulated amount of under-ground part is 91\% higher than the highest $\mathrm{Pb}$ content of above-ground part. It reflects the high accumulation amount of under-ground part of sagittaria sagittifolia.

Table 5-2 Effects of PbL stress on $\mathrm{Pb}$ accumulation of I. pseudacorus and S. sagittifolia $(X \pm S D)^{1}$

\begin{tabular}{cccc}
\hline & & Pb content & Pb concentration $(\mu \mathrm{g} / \mathrm{g})$ \\
Species & Treatment & & \\
& & Aboveground part & Underground part \\
& $0 \%$ & $6.25 \pm 1.25 \mathrm{c}$ & $26.94 \pm 5.67 \mathrm{~d}$ \\
iris & $25 \%$ & $33.93 \pm 7.78 \mathrm{c}$ & $105.50 \pm 10.40 \mathrm{c}$ \\
pseudacoru & $50 \%$ & $78.61 \pm 7.47 \mathrm{~b}$ & $121.04 \pm 16.30 \mathrm{c}$ \\
s & $75 \%$ & $90.42 \pm 18.97 \mathrm{~b}$ & $173.29 \pm 23.90 \mathrm{~b}$ \\
& $100 \%$ & $148.89 \pm 38.24 \mathrm{a}$ & $318.33 \pm 36.17 \mathrm{a}$ \\
sagittaria & $0 \%$ & $3.92 \pm 0.52 \mathrm{c}$ & $16.67 \pm 3.82 \mathrm{~d}$ \\
sagittifolia & $25 \%$ & $30.97 \pm 6.10 \mathrm{~b}$ & $53.33 \pm 8.78 \mathrm{~cd}$ \\
& $50 \%$ & $52.08 \pm 9.55 \mathrm{~b}$ & $80.83 \pm 20.05 \mathrm{c}$ \\
& $100 \%$ & $125.00 \pm 25.00 \mathrm{a}$ & $170.83 \pm 31.46 \mathrm{~b}$ \\
\hline
\end{tabular}

Different small letters in the same column indicate the significant difference by Duncan's new multiple range test $(P<0.05)$.

In $\mathrm{Pb}$ tailings exudated liquids with different contents, iris pseudacorus and sagittaria sagittifolia's translocation factors (TF)of $\mathrm{Pb}$ can be seen in Table 3. With the constant improvement of lead adding amounts in liquids, the translocation factors of iris pseudacorus and sagittaria sagittifolia continuously rise. The translocation factors of various treatments are all higher than the control group. Among them, the highest translocation factor of iris pseudacorus appears in $50 \% \mathrm{PbL}$ treatment and the highest translocation factor (TF) of sagittaria sagittifolia appears in $25 \% \mathrm{PbL}$ treatment. They are 2.8 times and 2.4 times of the control group respectively. In the treatment range from $0 \% \mathrm{PbL}$ to $100 \% \mathrm{PbL}$, the translocation factors of iris pseudacorus and sagittaria sagittifolia are both less than 1 , and it shows that $\mathrm{Pb}$ accumulation amounts of the underground part of the two kinds of aquatic plants are both higher than the aboveground part. 
Table 5-3 Effects of PbL stress on the translocation factors of Pb of I. pseudacorus and $S$. sagittifolia $(X \pm S D)^{1}$

\begin{tabular}{cccccc}
\hline \multirow{2}{*}{ Species } & \multicolumn{5}{c}{ Translocation factors } \\
\cline { 2 - 6 } & $0 \%$ & $25 \%$ & $50 \%$ & $75 \%$ & $100 \%$ \\
\cline { 2 - 6 } iris pseudacorus & 0.23 & 0.32 & 0.65 & 0.52 & 0.47 \\
$\begin{array}{c}\text { sagittaria } \\
\text { sagittifolia }\end{array}$ & 0.24 & 0.58 & 0.46 & 0.30 & 0.52 \\
\hline
\end{tabular}

\section{Discussion}

Studies have found that a certain amount of $\mathrm{Pb}$ can promote the growth of plants, but If the amount of $\mathrm{Pb}$ is overmuch, it can inhibit the physiological metabolism of plants, and even cause the plants to die. Seen from Table 5-1 Effects of PbL stress on the growth indexes of I. pseudacorus and $\mathrm{S}$. Sagittifolia, with the increase of $\mathrm{Pb}$ concentration, seeding height, root length, above-ground part and under-ground part in dry weight, and tolerance index of the two kinds of plants all show a trend of gradual decline. Among them, tolerance index of iris pseudacorus is $76 \%$, and tolerance index of sagittaria sagittifolia is $55 \%$. By comparison, iris pseudacorus's tolerance on $\mathrm{Pb}$ tailings exudated liquids is stronger than Sagittaria Sagittifolia.

If we evaluate the actual remediation effect of plants on polluted environment, eventually we should rely on the amount of targeted pollutants which the plants absorb and transfer from polluted environment. Therefore, $\mathrm{Pb}$ accumulation amount is relatively ideal index of measuring the plants' actual remediation ability on $\mathrm{Pb}$ polluted environment. In this experiment, with the increase of $\mathrm{Pb}$ concentration, $\mathrm{Pb}$ accumulation amounts of above-ground part and under-ground part of iris pseudacorus and sagittaria sagittifolia rise quickly. It shows that iris pseudacorus and sagittaria sagittifolia have stronger accumulation ability on $\mathrm{Pb}$.

The $\mathrm{pH}$ acts as the external environment induced factor of accumulating the heavy metals by aquatic plants. When the water body shows alkaline condition, it is easier for $\mathrm{Pb}$ element to form the suspended muddy thing. It is hard for plants to adsorb. However, when $\mathrm{pH}$ value range is from 5.0 to 7.0 , it is more likely to absorb heavy metal ion sedimentation. $\mathrm{pH}$ values of iris pseudacorus control group and treatment solution are both less than 7 . It shows that the sampling solution shows weak acid because of iris pseudacorus planting. In addition, the rise of treatment concentration and the increase of $\mathrm{Pb}$ ions lead to that acid degree in the solution is higher and higher. The $\mathrm{pH}$ values of Sagittaria Sagittifolia each treatment solution have more significant differences. The higher the solution concentration is, the smaller the $\mathrm{pH}$ value is. But they are all above 8 , and they show obvious alkaline. It is not very beneficial to absorb the heavy metal ion. However, under the $25 \% \mathrm{PbL}$ treatment of iris pseudacorus, the solution $\mathrm{PH}$ value is 5.32, and at this time plants can absorb heavy metal ions in solutions best.

In a word, under $\mathrm{Pb}$ tailings exudated liquids treatment, dissolved oxygen, electric conductivity, acidity and alkalinity ability in regulating solutions of iris pseudacorus and Sagittaria Sagittifolia are stronger. The two kinds of plants also have larger absorptive amount on $\mathrm{Pb}$ ions by themselves. It shows that the aquatic plants, iris pseudacorus and Sagittaria Sagittifolia can be used to mediate the water body environment with $\mathrm{Pb}$ heavy metal tailings pollution.

\section{References}

[1]Akcil A, Erust C, Ozdemiroglu S, Fonti V, Beolchini F. A Review of Approaches and Techniques Used in Aquatic Contaminated Sediments: Metal Removal and Stabilization by Chemical and Biotechnological Processes. Journal of Cleaner Production, 2015, 86:24 36.

[2]Guan Mengqian, Zhou Xudan, Dongran. Effects of Cu-Cd Composite Stress on the Growth of Two Kinds of Day Lilies and the Antioxidant Enzyme Activity[J]. Journal of Northwest Sci-Tech 
University of Agriculture and Forestry:Natural Science Edition, 2015(4): 15 19.

[3]Chuan Limin, Zhao Tongke, Zheng Huaiguo. Soil Heavy Metal Pollution Remediation Technology Research Progress[J]. Environment Science and Technology, 2014(S2).

[4]Zhang Kaiming, Tong Haiying, Huang Suzhen. Effects of Cu Stress on Iris Pseudacorus and Iris Ensata Thunb $\mathrm{Cu}$ and Accumulation and Other Nutrients Absorption[J]. Journal of plant resources and environment, 2007, 16(1): 18 22. 